\title{
Total or partial replacement of fishmeal with soybean meal in the diet of the Pacific fat sleeper Dormitator latifrons juveniles
}

\author{
Daniel Badillo-Zapata ${ }^{1,3}$, Gabriela E. Musin ${ }^{2}$, David J. Palma-Cancino ${ }^{1}$, Saúl R. Guerrero-Galván ${ }^{1}$ \\ Olimpia Chong-Carrillo ${ }^{1}$ \& Fernando Vega-Villasante ${ }^{1}$ \\ ${ }^{1}$ Laboratorio de Calidad de Agua y Acuicultura Experimental, Departamento de Ciencias Biológicas \\ Centro Universitario de la Costa, Universidad de Guadalajara, Puerto Vallarta, Jalisco, México \\ ${ }^{2}$ Instituto Nacional de Limnología, Consejo Nacional de Investigaciones Científicas y Técnicas (CONICET) \\ Universidad Nacional del Litoral, Santa Fe, Argentina \\ ${ }^{3}$ Cátedras CONACyT, Consejo Nacional de Ciencia y Tecnología, Ciudad de México, México \\ Corresponding author: Fernando Vega-Villasante (fernandovega.villasante @ gmail.com)
}

\begin{abstract}
Groups of Dormitator latifrons in triplicate $(4.1 \pm 2.0 \mathrm{~g}$ and $6.2 \pm 1.0 \mathrm{~cm})$ were fed experimental diets containing four levels of substitution of fishmeal (FM) by soybean meal (SM) (0, 40, 70, and 100\%, respectively). The diets were formulated to be isoproteic (35\% crude protein) and isolipidic (8.0\% crude lipids). The effect of each treatment on growth was evaluated and its implications on the cost of feeding. After 60 days of feeding, there were no significant differences in the fish's proximate composition $(P<0.05)$. There were no significant differences between the diets $(P<0.05)$ in the evaluated biological indices: total growth increase (TGI), specific growth rate (SGR), thermal growth coefficient (TGC), and survival (\%). Feeding costs decreased significantly as the proportion of soybean meal in the diet increased. The results indicated that substituting FM by up to $100 \%$ of SM can promote adequate growth in D. latifrons without affecting body composition and survival while also reducing operative costs during the fattening process.
\end{abstract}

Keywords: Dormitator latifrons; Eleotridae; native fish; nutrition; growth; bioeconomics; aquaculture

\section{INTRODUCTION}

In Mexico, most studies of species with aquaculture potential have focused on marine species. In contrast, the inland aquaculture industry relies mostly on exotic species such as tilapia (Oreochromis spp.) and carp (Cyprinidae family). Native freshwater species with high productive potential have been poorly studied. One of these species is Dormitator latifrons (Richardson 1844), also called fat sleeper, chame, puyeque, popoyote, chococo, or chalaco. Belongs to the diadromous fish group, particularly to the amphidromous fishes, spawns in freshwater bodies; the larvae migrate to the sea and then return to freshwater, where they will spend the rest of their development (Milton 2009). It is distributed along with Pacific coastal areas and estuaries, from California (USA) to southern Peru. In Ecuador, D. latifrons is considered a fishery and aquaculture resource. That country has accumulated the greatest wealth of empirical knowledge on this species, as it is a key ingredient of traditional gastronomy and is cultivated from wild hatchlings. (Arriaga \& Martínez 2003, Schwarz 2007, Rodríguez et al. 2012). In Mexico, there have been studies on the cultivation of D. latifrons (Basto-Rosales et al. 2019), on the quality of its meat (López-Huerta et al. 2018, Basto-Rosales et al. 2020), and the nutritional requirements of juvenile fish (Badillo-Zapata et al. 2018). However, alternative diets on the growth and production costs of this species have not been studied yet. Regarding its nutritional value, it was demonstrated that $D$. latifrons has good essential amino acid.

Numerous studies have focused on finding alternative ingredients as the main source of protein in fish feed, some of vegetable origin (soybeans, wheat, peas, grains or oilseeds, among others), others of animal origin (poultry meal, blood meal, feather meal) (Li et al. 2011, 2020, Badillo et al. 2014, Pares-Sierra et al. 2014, Tangendjaja 2015, Wang et al. 2017, Tran et al. 2019, Ye et al. 2019). Soybean meal (SBM) has 
been recognized as one of the most appropriate alternative protein sources for fishmeal in aquafeed because of its wide availability, sustainable supply chain, reasonable price, high protein content (45-50\%), and adequate amino acid profile (Lin \& Luo 2011). Soybean meal is a great candidate for substituting fishmeal for cultivated fish species (Wang et al. 2017, Ye et al. 2019). Finding cheaper alternative diets that do not affect the growth during cultivation is essential to consolidate the production of native fishes (Tran et al. 2019). Highlighting the importance of cost reduction by substituting some diet formulation ingredients with less expensive alternatives, but obtaining acceptable nutrition and growth results with partial or total replacement (Poot-López et al. 2010).

With the aim of beginning to lay the foundations for the future establishment of $D$. latifrons as a species with a commercial interest and sustainable rural production in Mexico, the present study evaluates the effect of the substitution of fishmeal by soybean meal on the growth, body composition, digestibility, survival, and feed costs associated with the juveniles of this native fish.

\section{MATERIALS AND METHODS}

\section{Collection of specimens}

Juveniles of Dormitator latifrons (200) were captured using a fishing net in the El Quelele Lagoon $\left(20^{\circ} 43^{\prime} 25.43^{\prime \prime} \mathrm{N}, 105^{\circ} 18^{\prime} 03.63^{\prime \prime} \mathrm{W}\right)$, located in the state of Nayarit, Mexico. The fish were transported under constant aeration $\left(4 \mathrm{mg} \mathrm{O}_{2} \mathrm{~L}^{-1}\right)$ in a $400 \mathrm{~L}$ container to the Laboratory of Water Quality and Experimental Aquaculture (LACUIC) of the Centro Universitario de la Costa (CUCosta), in the University of Guadalajara (UdeG) in Puerto Vallarta, Jalisco, Mexico. Before distributing the fish in the culture tanks, they were subjected to an ectoparasite removal treatment with Dimilin ${ }^{\circledR}$ (diflubenzuron 22\%), at a concentration of $300 \mu \mathrm{g} \mathrm{L}^{-1}$ diflubenzuron, in a $200 \mathrm{~L}$ container for 10 $\min$. The fish were kept in a seven-day quarantine in $500 \mathrm{~L}$ reservoir tanks with constant recirculation. During this period, the fish were fed once a day with commercial feed containing 30\% protein and $8 \%$ lipids $\left(\right.$ Purina $\left.{ }^{\circledR}\right)$, dissolved oxygen was monitored daily using an oximeter (YSI $\left.{ }^{\circledR} 550 \mathrm{~A}\right)$.

\section{Preparation of the diets}

A completely randomized experimental design with four treatments (diets), each in triplicate, was used with the iso-nitrogenous (crude protein concentration, 35\%) and iso-lipidic (lipid 8\%) requirements proposed by Badillo-Zapata et al. (2018). Fishmeal was substituted by $0,40,70$, and $100 \%$ of soybean meal (SM0, SM40,
SM70, SM100, respectively) (Table 1). The ingredients were weighed on a precision balance (Nimbus ${ }^{\circledR}$ NBL8201e) and then mixed and homogenized (with the appropriate amount of water) in a mixer (Blazer Torrey ${ }^{\circledR}$ model B10); the resulting mixture was pelletized ( $3 \mathrm{~mm}$ pellets) in a mill (Torrey ${ }^{\circledR}$ model M12-FS). The material was then dried in an oven $\left(\right.$ Novatech $\left.^{\circledR}\right)$ at $60^{\circ} \mathrm{C}$ for $24 \mathrm{~h}$, packed in plastic bags, and stored at $-20^{\circ} \mathrm{C}$ until use.

\section{Design and experimental system}

Fish were randomly distributed in 12 experimental units (EU), consisting of a $300 \mathrm{~L}$ plastic tank with constant aeration and $30 \%$ weekly water exchange. Each EU contained ten specimens with an initial weight of $4.1 \pm 2.0 \mathrm{~g}$ and an initial size of $6.2 \pm 1.0 \mathrm{~cm}$. During 60 days, the organisms in each EU were fed twice a day (9:00 and $16: 00 \mathrm{~h}$ ) with the corresponding experimental diet; the amount of feed provided corresponded to 5\% of each EU's total biomass. Feces and non-consumed food were removed daily (using a siphon) during the feeding period. Feces were later used to test the apparent digestibility of each diet. The photoperiod was set to 12:12 h (light:dark) using timers. Temperature, dissolved oxygen, and $\mathrm{pH}$ were daily monitored using an oximeter ( $\mathrm{YSI}^{\circledR} 550 \mathrm{~A}$ ), averaging $27.7 \pm 1.4^{\circ} \mathrm{C}, 3.84$ $\pm 0.86 \mathrm{mg} \mathrm{L}^{-1}$, and $7.87 \pm 0.24$, respectively, throughout the experiment. Two biometric measurements were performed. The total weight $(\mathrm{g})$ was recorded at the beginning and the end of the experimental period, with a digital scale (Ohaus ${ }^{\circledR}$ PR2201) and total length (cm) with an ichthyometer; the length of each fish, was measured from the most anterior part of the head to the most posterior part of the tail fin.

\section{Chemical analysis}

Proximate composition of diets and whole organism were measured (in triplicate 10-15 g) for each treatment and experimental unit and expressed on dry matter basis according to standard procedures of the Association of Official Analytical Chemists (AOAC 1990). After 60 days of experimentation, all the fish in the EU were captured and subjected to a thermal shock by cold (Díaz-Villanueva \& Robotham 2015). Six whole organisms aleatory per tank were pooled and blended for analysis. Total nitrogen content was determined using the micro-Kjeldahl method (Novatech ${ }^{\circledR}$ model KJR), and percent crude protein was then calculated as $\% \mathrm{~N}$ and multiplied by a factor of 6.25. Total lipids concentration was determined by the Soxhlet extraction method $\left(\right.$ Novatech $\left.{ }^{\circledR}\right)$ using hexane as the carrier solvent, and the crude fat was calculated gravimetrically. Ash content was estimated by heating samples to $550^{\circ} \mathrm{C}$ for $6 \mathrm{~h}$, using a muffle digital 
Table 1. Ingredients, cost of the diets, feed expenses, proximate composition, and digestibility coefficient of the experimental diets with different substitution levels of fishmeal by soybean meal. The diets were used to feed juvenile Dormitator latifrons fish. Different letters in the same row indicate significant differences $(P<0.05)$. ${ }^{1}$ Proteínas Marinas y Agropecuarias, S.A. de CV, Guadalajara, Jalisco, México. ${ }^{2}$ Sistemas en Zootecnia S.A. de C.V., Tlajomulco de Zuñiga, Jalisco, México. ${ }^{3}$ Input prices quoted by sellers and updated to 2020 . ${ }^{*}$ Based on $23.4 \mathrm{KJ} \mathrm{g}^{-1}$ of protein, $39.2 \mathrm{KJ} \mathrm{g}^{-1}$ of lipids, and $17.2 \mathrm{KJ} \mathrm{g}^{-1}$ of NFE. Digestibility coefficient five days before the end of the experimental period (\%), values are presented as mean \pm standard deviation (SD) $(\mathrm{n}=3)$. For costs, total feed consumed, the total cost of feed and digestibility coefficient, different superscripts letter in the same raw indicate statistical differences $(P<0.05)$.

\begin{tabular}{|c|c|c|c|c|}
\hline \multirow{2}{*}{ Ingredients } & \multicolumn{4}{|c|}{ Experimental treatments } \\
\hline & HSO & HS40 & HS70 & HS100 \\
\hline Fishmeal $^{1}$ & 35.2 & 21.1 & 10.6 & 0 \\
\hline Cornmeal & 8.6 & 8.6 & 8.6 & 8.6 \\
\hline Soybean meal ${ }^{1}$ & 0 & 20 & 35.1 & 50.1 \\
\hline Fish oil $^{1}$ & 5.3 & 4.8 & 5.5 & 5.2 \\
\hline Corn oil & 0 & 1.2 & 1.2 & 2.2 \\
\hline Cornstarch & 41.1 & 34.4 & 29.3 & 24.2 \\
\hline Gelatin & 6 & 6 & 6 & 6 \\
\hline Vitamin $C^{2}$ & 0.4 & 0.4 & 0.4 & 0.4 \\
\hline Vitamins and minerals ${ }^{2}$ & 3 & 3 & 3 & 3 \\
\hline Sodium benzoate & 0.2 & 0.2 & 0.2 & 0.2 \\
\hline Choline chloride $^{2}$ & 0.1 & 0.1 & 0.1 & 0.1 \\
\hline Tocopherol & 0.01 & 0.01 & 0.01 & 0.01 \\
\hline Total (g) & 100 & 100 & 100 & 100 \\
\hline Cost per $100 \mathrm{~g}$ of diet (USD) ${ }^{3}$ & $0.27^{\mathrm{a}}$ & $0.23^{\mathrm{ab}}$ & $0.19^{\mathrm{b}}$ & $0.16^{\mathrm{b}}$ \\
\hline Total feed consumed $(\mathrm{g})$ & $594^{\mathrm{ab}}$ & $621^{b}$ & $544.5^{\mathrm{a}}$ & $580.5^{\mathrm{a}}$ \\
\hline Total cost of feed (USD) & $1.60^{\mathrm{a}}$ & $1.41^{\mathrm{a}}$ & $1.06^{\mathrm{b}}$ & $0.94^{\mathrm{b}}$ \\
\hline \multicolumn{5}{|c|}{ Proximate composition (\% of dry matter) } \\
\hline Total proteins $(\%)$ & 35.1 & 35.3 & 36 & 34.6 \\
\hline Total fat $(\%)$ & 7.9 & 7.6 & 7.6 & 7.9 \\
\hline $\operatorname{Ash}(\%)$ & 13.3 & 10.6 & 8.2 & 6.6 \\
\hline NFE & 43.7 & 46.5 & 48.2 & 50.9 \\
\hline Net energy $\left(\mathrm{KJ} \mathrm{g}^{-1}\right)^{*}$ & 19.1 & 19.6 & 20.2 & 20.3 \\
\hline Digestibility coefficient (\%) & $64.0 \pm 2.6^{\mathrm{a}}$ & $63.3 \pm 0.6^{\mathrm{a}}$ & $93.2 \pm 0.2^{c}$ & $85.9 \pm 0.6^{b}$ \\
\hline
\end{tabular}

$\left(\right.$ Novatech $\left.^{\circledR}\right)$. The nitrogen-free extract was calculate by differences of dry matter and include soluble and insoluble carbohydrates $[$ NFE $(\%)=100-(\%$ crude protein $+\%$ total lipids $+\%$ ash) $]$.

\section{Apparent digestibility of the diets}

Each EU's bottom was cleaned after feeding, using a filtered siphon to avoid collecting food remnants to determine the diets' coefficient of apparent digestibility. Two hours later, feces were collected from the bottom of each EU and dried in an oven at $60^{\circ} \mathrm{C}$ for 24 $\mathrm{h}$. The dried feces were then placed in plastic containers and refrigerated at $-20^{\circ} \mathrm{C}$ until analysis. This method was repeated for 15 days until the end of the assay.

The apparent digestibility (AD) was determined using the insoluble acid ash (AIA) technique of Van Keulen \& Young (1977), modified by Montaño-Vargas et al. (2002). The content of acid-insoluble ash was determined in both feed and feces, using the following formulas:

$$
\begin{gathered}
A D(\%)=100-\left(\frac{100 \times \% \text { AIA feed }}{\% \text { AIA feces }}\right) \\
\text { AIA }(\%)=\left(\frac{\text { sample weight }+ \text { ashes }(g)-\text { crucible weight }(g)}{\text { dry sample weight }(g)}\right) \times 100
\end{gathered}
$$

\section{Growth indices}

Growth indices were determined for each treatment, evaluating weight increase, survival, and the following biological indices, calculated using the formulas specified below:

Total growth increase (TGI) $(\%): T G I=\left(\frac{\text { weight }_{\text {final }}(g)}{\text { weight }_{\text {initial }}(g)}\right) \times 100$

Growth rate $(\mathrm{GR})\left(\mathrm{g} \mathrm{d}^{-1}\right): G R=\left(\frac{\text { weight }_{\text {final }}(g)-\text { weight }_{\text {initial }}(g)}{\text { Time }(d)}\right)$

Specific growth rate (SGR) $\left(\% \mathrm{~d}^{-1}\right)$ :

$S G R=\left(\frac{\ln \text { weigth }_{\text {final }}(g)-\text { ln weight }_{\text {initial }}(g)}{\text { Time }(d)}\right) \times 100$ 
Thermal growth coefficient (TGC):

$T G C$

$=\left(\frac{\sqrt[3]{\text { weight }_{\text {final }}(g)}-\sqrt[3]{\text { weight }} \text { initial }(g)}{\text { mean water temperature }\left({ }^{\circ} \mathrm{C}\right) \times \text { time }(\text { day })}\right) \times 1000$

\section{Feeding costs}

Feeding costs $(\mathrm{Fc})$ were evaluated for each treatment to relate the effect on growth and production cost for the substitution of fishmeal by soybean meal on juveniles of D. latifrons. The prices of the inputs and the quantities required for the elaboration of the diets were quantified. The amount of feed provided to each treatment during the culture period was also quantified using the $5 \%$ of total biomass daily. The cost per gram of feed $(\mathrm{Hc})$ was calculated for each treatment and multiplied by the amount of food (f) provided and the time $(\mathrm{t})$. The formula used was as follows:

$$
F c=H c \times(f \times t)
$$

\section{Statistical analysis}

The data were subjected to homogeneity tests to decide whether to use parametric or nonparametric methods. One-way analysis of variance (ANOVA) was used to determine differences between treatments. When significant differences $(P<0.05)$ were found, a posthoc Tukey's test was used to identify statistical differences in digestibility and the proximate analysis between treatments. A means contrast test was also performed. Statistical significance was set at $P<0.05$, and the results are presented as mean \pm standard deviation. All statistical analyzes were done using StatSoft ${ }^{\circledR}$ Statistica 12.0.

\section{RESULTS}

The biological indices used in this experiment did not show statistical differences between treatments $(P<$ 0.05) (Table 2). However, fish fed with the HS40 diet showed the greatest increase in weight $(9.7 \pm 2.4 \mathrm{~g})$ and whole carcass protein content $(61.3 \pm 0.9 \%)$, while fish treated with the HSO diet was associated with the highest survival rate $(96.7 \pm 5.8 \%)$ (Table 2$)$.

Regarding fat and ash content, fishes treated with the HS70 and HS100 diets showed significant statistical differences. The HSO and HS40 diets were associated with the lowest fat percentages in fish $(12.3 \pm 0.3$ and $12.3 \pm 0.2 \%$, respectively), while the lowest percentage of ash content was associated with the HS100 diet (12.3 $\pm 0.1 \%$ ). The nitrogen-free extract (NFE) found in the fish did not show statistical differences; however, the HSO diet was presented the highest percentage (13.7\%), as shown in Table 3.
Significant differences were also found in the coefficient of apparent digestibility $(P<0.05)$. At the end of the 60 days the experimental feeding period, the HSO and HS40 diets $(64.0 \pm 2.6$ and $63.3 \pm 0.6 \%$, respectively) showed significantly different results than the other diets, with the HS70 and H100 diets showing the highest digestibility values $(93.2 \pm 0.7$ and $85.9 \pm$ $0.6 \%$, respectively) (Table 1 ).

Feeding costs decreased significantly as the percentage of soybean meal increased (Table 1). The fish under the HS40 treatment consumed the largest feed during the experimental feeding period (621 g), while the lowest feed consumption corresponds to the fish under the HS70 treatment (544.5 g).

\section{DISCUSSION}

Generally, freshwater fish species have been associated with good results in terms of growth, survival, and feed yield when provided with vegetable protein sources at substitution levels of $80 \%$ or even $100 \%$ (Zhao et al. 2016), while marine species tolerate only low replacement levels (Wang et al. 2017).

Soybean meal is widely used as the primary protein source in different formulations due to its nutritional composition, ample availability, and low cost (Gatlin et al. 2007, Tangendjaja 2015, Wang et al. 2017, Bruce et al. 2018, Ye et al. 2019). Numerous studies have demonstrated the feasibility of substituting fishmeal in the diet of various fish species of commercial interest without affecting their growth or productivity (Elangovan \& Shim 2000, Heikkinen et al. 2006, Bruce et al. 2018, Zhang et al. 2018). However, the availability and utilization of nutrients in fish feed vary with the type of processing methods used to produce soybean meal (Tangendjaja 2015, Bruce et al. 2018). These differences might be associated with antinutritional components such as trypsin inhibitors, phytic acid, and saponins, among others, which can have adverse effects on nutrient digestibility and assimilation, affecting fish growth (Gatlin et al. 2007, Wang et al. 2017).

One method to verify the quality of a diet ingredient is to carry out controlled feeding studies with the species of interest, testing the effects of increasing amounts of the ingredient (Tangendjaja 2015). Like Dormitator latifrons in this research, omnivorous fishes had shown great acceptance to fishmeal substitution with soybean meal. Studies like those of Lin \& Luo (2011) on Oreochromis niloticus, with $100 \%$ substitution; and Zhang et al. (2018) on Lateolabrax japonicus, with $70 \%$ substitution; showed an inverse 
Table 2. Biological indices of juvenile Dormitator latifrons fish fed with different levels of substitution of fishmeal by soybean meal. GR: growth rate, SGR: specific growth rate, TGC: thermal growth coefficient. Different letters in the same row indicate significant differences $(P<0.05)$. Values on the same line with different letters show statistically significant differences $(P<0.05)$.

\begin{tabular}{lcccc}
\hline \multirow{2}{*}{ Biological indices } & \multicolumn{4}{c}{ Experimental treatments } \\
\cline { 2 - 5 } & HS0 & HS40 & HS70 & HS100 \\
\hline Initial weight $(\mathrm{g})$ & $4.1 \pm 2.0$ & $4.1 \pm 2.0$ & $4.1 \pm 2.0$ & $4.1 \pm 2.0$ \\
Final weight $(\mathrm{g})$ & $9.1 \pm 3.0$ & $9.7 \pm 2.4$ & $8.0 \pm 1.0$ & $8.8 \pm 1.6$ \\
Weight gained (\%) & $222.7 \pm 72.9$ & $236.2 \pm 58.5$ & $194.3 \pm 24.4$ & $215.4 \pm 38.5$ \\
GR $\left(\mathrm{g} \mathrm{d}^{-1}\right)$ & $0.1 \pm 0.1$ & $0.1 \pm 0.05$ & $0.1 \pm 0.02$ & $0.1 \pm 0.04$ \\
SGR $\left(\% \mathrm{~d}^{-1}\right)$ & $2.5 \pm 0.9$ & $2.7 \pm 0.9$ & $2.2 \pm 0.5$ & $2.5 \pm 20.6$ \\
TGC & $0.3 \pm 0.1$ & $0.3 \pm 0.1$ & $0.2 \pm 0.1$ & $0.3 \pm 0.1$ \\
Survival $(\%)$ & $96.7 \pm 5.8$ & $93.3 \pm 11.5$ & $86.7 \pm 15.3$ & $90.0 \pm 10.0$ \\
\hline
\end{tabular}

Table 3. Proximate analysis of whole juvenile Dormitator latifrons fish fed different substitution levels $(0,40,70$, and $100 \%)$ of fishmeal by soybean meal. Different letters in the same row indicate significant differences $(P<0.05)$. Values are shown as mean \pm standard deviation $(\mathrm{n}=3)$. Super indices indicate statistically significant differences $(P<0.05)$.

\begin{tabular}{|c|c|c|c|c|c|}
\hline \multirow{3}{*}{ Proximate analysis } & \multicolumn{5}{|c|}{ Experimental treatments } \\
\hline & \multirow{2}{*}{ Initial fish } & \multicolumn{4}{|c|}{ Final fish } \\
\hline & & HSO & HS40 & HS70 & HS100 \\
\hline Crude & $57.6 \pm 0.6$ & $58.8 \pm 1.4$ & $61.3 \pm 0.9$ & $59.9 \pm 1.0$ & $60.7 \pm 3.4$ \\
\hline Crude fat $(\%)$ & $13.4 \pm 0.4$ & $12.3 \pm 0.3^{\mathrm{a}}$ & $12.3 \pm 0.2^{\mathrm{a}}$ & $13.8 \pm 0.7^{b}$ & $15.8 \pm 0.3^{\mathrm{c}}$ \\
\hline $\operatorname{Ash}(\%)$ & $15.4 \pm 0.4$ & $15.3 \pm 0.1^{\mathrm{c}}$ & $14.7 \pm 0.2^{\mathrm{c}}$ & $13.6 \pm 0.1^{\mathrm{b}}$ & $12.3 \pm 0.1^{\mathrm{a}}$ \\
\hline Nitrogen-free extract & 13.4 & 13.7 & 10.5 & 11.3 & 11.2 \\
\hline
\end{tabular}

relationship between the percentage of substitution and growth rate and sustained good growth results when replacing fishmeal by $50 \%$ or higher. In carnivorous fish, the replacement of fishmeal with soybean meal has proved to affect the growth. Tibaldi et al. (2006) found that substituting FM by more than 50\% SBM affected intestinal enzymatic activity, directly associated with the digestibility and bioavailability of nutrients. Similar results were reported by Elangovan \& Shim (2000), substituted FM by a maximum of 50\% of SBM for Barbodes altus affected the growth of the organisms under study.

The use of soybean meal as a substitute for fishmeal in the feed of $D$. latifrons had no negative growth effects after 60 days. Concerning the digestibility coefficient, the diets containing between 70 and $100 \%$ of SBM had better nutrient digestibility values (80$90 \%$ ) compared to the diet with $100 \%$ FM (Table 1). Kasiga et al. (2020) mention that the digestibility of a food or an experimental diet is a crucial factor and that few studies evaluate when the use of a diet is being evaluated, this factor reflects the percentage of a food sample that is absorbed in the intestine of an animal.

Diets with the same percentage of proteins and lipids, but with different levels of substitution of fishmeal by soybean meal, positively affected the proximate composition of juvenile D. latifrons fish; protein and lipids' content increased as the percentage of substitution with soybean increased. Kaushik et al (2004), studying the European sea bass (Dicentrarchus labrax), obtained good growth and nitrogen retention results with only $5 \%$ of fishmeal and $95 \%$ of vegetable protein sources in the diet, including soybean meal; however, the authors found that the fish had a significantly increased content of fat (15.6\%) compared to the fish fed with the control diet containing $100 \%$ of fishmeal. The present study recorded a similar trend.

The fact that, in the present study, total fat showed a tendency to increase as fishmeal was replaced by soybean meal contrasts with the results of other studies that have shown that high soybean meal levels tend to reduce fat digestibility in fish with generally carnivorous habits (Tibaldi et al. 2006). Due to the origin of the SBM use during our research, some authors suggest the SBM's production process may affect the performance of digestibility for commercial fish (Tangenjadja 2015, Bruce et al. 2018). Olli \& Krogdahl (1995) evaluated the effect of including different levels of a concentrate of alcohol-soluble soybean meal (soy molasses) in fishmeal-based diets used to feed Atlantic salmon (Salmo salar). They reported that the SBM's alcohol-soluble components 
contained antinutrients that negatively affected fat digestibility and may have been responsible for a significant part of the negative effects of the standard soybean meal.

Regarding feeding costs, the complete substitution of FM by SBM makes a considerable difference compared to $100 \%$ FM (Table 1). The present study results showed that it is cheaper to produce the HS100 diet, but the fish fed with it contain more protein and are thus of better nutritional quality. The latter can improve the species' market performance based on the idea that more protein may diversify the presentation of the product (fillet, fish medallion), and the lowered feeding costs mitigate new marketing costs by this process. Ajani et al. (2016) obtained O. niloticus of better nutritional quality using SBM as a protein source in their diet, resulting in lower input costs improving income and utility on the farm.

The reduction of costs obtained in the present work, a result of substituting animal protein with plant protein in the diet of juvenile $D$. latifrons fish, coincides with the results obtained by several authors in similar studies. Robinson \& Li (2010) found a reduction in production costs by feeding Ictalurus punctatus fish with a diet in which fishmeal was partially or entirely substituted by corn gluten or cottonseed meal. PootLópez et al. (2010) obtained a considerable reduction in management and operating costs, with no negative effect on growth, by partially substituting a balanced diet fed to O. niloticus with tree spinach (Cnidoscolus chayamansa) waste at satiety. According to Subedi et al. (2019), the minimization of costs in aquaculture resulting from the substitution of FM by SBM would allow for optimization of the cost-benefit ratio when scaling up production to commercial scale based on bio-economic models of tropical fish production that indicate that food represents the most significant expense in aquaculture (Okwu \& Acheneje 2011, Hernández et al. 2014).

The commercial value of wild $D$. latifrons fish in rural areas of the Mexican Pacific coast is still relatively low, USD 1.3 on average for a dozen fish (whole), ranging from 13 to $16 \mathrm{~cm}$ in size, which corresponds to approximately $1 \mathrm{~kg}$. The average price of the fillet is USD 2.2 per kg. (Basto-Rosales et al. 2020). If feeding costs could be reduced without affecting the protein content of the meat, it might be possible to find a broader market for farmed $D$. latifrons fish with a marketing strategy focused on the nutritional qualities and lower price of this fish, as has been done with other native species in regions such as Africa (Tran et al. 2019). Promoting the consumption of D. latifrons would help revert the displacement of this native species by introduced species, similar to what has been done in the Mediterranean with marine fish (Katsanevakis et al. 2014).

It is important to study the nutritional value of alternative ingredients to formulate diets based on a mixture of vegetable proteins that can partially or replace FM in the cultured fish diet (Poot-López et al. 2010, Li et al. 2020). Using higher levels of substitution of fishmeal by plant protein sources has shown to be feasible by using mixtures of ingredients (Kaushik et al. 2004). The possible effects of soybean meal on fish nutrition are associated with the method of presentation of the feed to the fish, the methods used to process the soybeans, and the age, species, and dietary habits of the cultured fish (Zhou et al. 2017).

The results obtained in the present work indicate that fishmeal can be substituted by up to $100 \%$ soybean meal in the diet of juvenile D. latifrons fish. This substitution yields adequate growth, high survival rates, good nutritional qualities in the cultured fish, and reduced production costs.

\section{ACKNOWLEDGMENTS}

Daniel Badillo wishes to thank CONACyT and the Cátedras project of CONACyT for the support provided for carrying out this study. To M.Sc. Ana Zapata, for her collaboration during the experimental assay. All authors express that the experimental assay was carried out according to the University of Guadalajara's code of ethics and following international guidelines.

\section{REFERENCES}

Ajani, E.K., Orisasona, O., Omitoyin, B.O. \& Osho, E.F. 2016. Total replacement of fishmeal by soybean meal with or without methionine fortification in the diets of Nile tilapia, Oreochromis niloticus. Journal of Fisheries and Aquatic Science, 11: 238-243. doi: 10.3923/jfas.2016.238.243

Arriaga, M.L. \& Martínez, O.J. 2003. Plan de ordenamiento de la pesca y acuicultura del Ecuador. Subsecretaría de Recursos Pesqueros, Guayaquil.

Association of the Official Analytical Chemists (AOAC). 1990. Official methods of analysis of the Association of the Official Analytical Chemists. AOAC, Washington, DC.

Badillo-Zapata, D., Lazo, J.P., Herzka, S.Z. \& Viana, M.T. 2014. The effect of substituting fishmeal with poultry by-product meal in diets for Totoaba macdonaldi juveniles. Aquaculture Research, 47: 1778-1789. doi: 10.1111/are.12636

Badillo-Zapata, D., Zaragoza, F.J., Vega-Villasante, F., López-Huerta, J.M., Herrera-Reséndiz, S., Cueto- 
Cortés, L. \& Guerrero-Galván, S.R. 2018. Requerimiento de proteína y lípidos para el crecimiento de juveniles del pez nativo Dormitator latifrons (Richardson, 1844). Ecosistemas y Recursos Agropecuarios, 5: 345-351. doi: 10.19136/era.a5n14.1554

Basto-Rosales, M.E.R., Rodríguez-Montes de Oca, G.A., Carrillo-Farnés, O., Álvarez-González, C.A., BadilloZapata, D. \& Vega-Villasante, F. 2019. Growth of Dormitator latifrons under different densities in concrete tanks. Tropical and Subtropical Agroecosystems, 22: 489-493.

Basto-Rosales, M.E.R., Carrillo-Farnés, O., MontoyaMartínez, C.E., Badillo-Zapata, D., Rodríguez-Montes de Oca, G.A., Álvarez-González, C.A., et al. 2020. Meat protein quality of Dormitator latifrons (Pisces: Eleotridae): arguments for use by rural communities. Ecosistemas y Recursos Agropecuarios, 7: e2172. doi: 10.19136/era.a7n1.2172

Bruce, T.J., Neiger, R.D. \& Brown, M.L. 2018. Gut histology, immunology and the intestinal microbiota of rainbow trout, Oncorhynchus mykiss (Walbaum), fed process variants of soybean meal. Aquaculture Research, 49: 492-504. doi: 10.1111/are. 13480

Díaz-Villanueva, J. \& Robotham, H. 2015. Comparación de dos métodos de sacrificio en trucha arcoíris (Oncorhynchus mykiss). Latin American Journal of Aquatic Research, 43: 287-94. doi: 10.3856/vol43issue2-fulltext-3

Elangovan, A. \& Shim, K.F. 2000. The influence of replacing fish meal partially in the diet with soybean meal on growth and body composition of juvenile tin foil barb Barbodes altus. Aquaculture, 189: 133-144. doi: 10.1016/S0044-8486(00)00365-3

Gatlin, D.M., Barrows, F.T., Brown, P., Dabrowski, K., Gaylord, T.G., Hardy, R.W. \& Herman, E. 2007. Expanding the utilization of sustainable plant products in aquafeeds: a review. Aquaculture Research, 38: 551-579. doi: 10.1111/j.1365-2109.2007.01704.x

Heikkinen, J., Kiuru, T., Navia-Paldanius, D., Kemiläinen, O., Wright, A.V., Vielma, J., et al. 2006. Effects of soybean meal-based diet on growth performance, gut histopathology, and intestinal microbiota of juvenile rainbow trout (Oncorhynchus mykiss). Aquaculture, 261: 259-268. doi: 10.1016/j. aquaculture.2006.07.012

Hernández, M., Gasca-Leyva, E., Gressler, P. \& Krise, D. 2014. Effect of farm and commercial inputs on carp polyculture performance: participatory trial in an experimental field station. Latin American Journal of Aquatic Research, 42: 468-476. doi: 10.3856/vol42issue3-fulltext-7

Kasiga, T., White, B., Bruce, T. \& Brown, M. 2020. Effect of fish meal replacement with Carinata Brassica carinata in low animal protein diets of rainbow trout Oncorhynchus mykiss (Walbaum) on trypsin activity, protein and amino acid digestibility and bioavailability. Aquaculture Research, 51: 2134-2149.

Katsanevakis, S., Wallentinus, I., Zenetos, A., Leppäkoski, E., Cinar, M.E., Oztürk, B., et al. 2014. Impacts of invasive alien marine species on ecosystem services and biodiversity: a pan-European review. Aquatic Invasions, 9: 391-423. doi: 10.3391/ai.2014.9. 4.01

Kaushik, S.J., Covès, D., Dutt, G. \& Blanc, D. 2004. Almost total replacement of fish meal by plant protein sources in the diet of a marine Teleost, the European seabass, Dicentrarchus labrax. Aquaculture, 230: 391404. doi: 10.1016/S0044-8486(03)00422-8

López-Huerta, J.M., Vega-Villasante, F., Viana, M.T., Carrillo-Farmés, O. \& Badillo-Zapata, D. 2018. First report of nutritional quality of the native fish Dormitator latifrons (Richardson, 1844) (Perciformes: Eleotridae). Latin American Journal of Aquatic Research, 46: 849-854. doi: 10.3856/vol46-issue4fulltext-24

Li, M.H., Robinson, E.H., Bosworth, B.G., Oberle, D.F. \& Lucas, P.M. 2011. Use of corn gluten feed and cottonseed meal to replace soybean meal and corn in diets for pond-raised channel catfish. North American Journal of Aquaculture, 73: 153-158. doi: 10.1080/ 15222055.2011.568857

Li, Y., Kortner, T.M., Chikwati, E.M., Belghit, I., Lock, E.Y. \& Krogdahl, A. 2020. Total replacement of fish meal with black soldier fly (Hermetia illucens) larvae meal does not compromise the gut health of Atlantic salmon (Salmo salar). Aquaculture, 734957. doi: 10.1016/j.aquaculture.2020.734967

Lin, S. \& Luo, L. 2011. Effects of different levels of soybean meal inclusion in replacement for fish meal on growth, digestive enzymes and transaminase activities in practical diets for juvenile tilapia, Oreochromis niloticus $\times$ O. aureus. Animal Feed Science and Technology, 168: 80-87. doi: 10.1016/ j.anifeedsci.2011.03.012

Milton, D.A. 2009. Living in two worlds: diadromous fishes, and factors affecting population connectivity between tropical rivers and coasts. In: Nagelkerken, I. (Ed.). Ecological connectivity among tropical coastal ecosystems. Springer, Dordrecht, pp. 325-355.

Montaño-Vargas, J., Shimada, A., Vásquez, C. \& Viana, M.T. 2002. Methods of measuring feed digestibility in the green abalone (Haliotis fulgens). Aquaculture, 213: 339-346. doi: 10.1016/S0044-8486(02)00020-0

Okwu, O.J. \& Acheneje, S. 2011. Socio-economic analysis of fish farming in Makurdi local government area, Benue State, Nigeria. European Journal of Social Sciences, 23: 508-519.

Olli, J.J. \& Krogdah, Å.L. 1995. Alcohol soluble components of soybeans seem to reduce fat digestibility in fish-meal-based diets for Atlantic salmon, 
Salmo salar L. Aquaculture Research, 26: 831-835. doi: 10.1111/j.1365-2109.1995.tb00876.x

Pares-Sierra, G., Durazo, E., Ponce, M.A., BadilloZapata, D., Correa-Reyes, G. \& Viana, M.T. 2014. Partial to total replacement of fishmeal by poultry byproduct meal in diets for juvenile rainbow trout (Oncorhynchus mykiss) and their effect on fatty acids from muscle tissue and the time required to retrieve the effect. Aquaculture Research, 45: 1459-1469. doi: 10.1111/are. 12092

Poot-López, G.R., Hernández, J.M. \& Gasca-Leyva, E. 2010. Input management in integrated agricultureaquaculture systems in Yucatan: tree spinach leaves as a dietary supplement in tilapia culture. Agricultural Systems, 103: 98-104.

Rodríguez-Montes de Oca, G., Medina-Hernández, E., Velázquez-Sandoval, J., López, V.V., Román, J.C., Dabrowski, K. \& Haws, M.C. 2012. Producción de chame (Dormitator latifrons, Piscis: Eleotridae) larvas usando GnRHa y LHRHa. Revista Colombiana de Ciencias Pecuarias, 25: 422-429.

Schwarz, L.G. 2007. Freshwater fish seed resources in Ecuador. In: Bondad-Reantaso, M.G. (Ed.). Assessment of freshwater fish seed resources for sustainable aquaculture. FAO, Rome, pp. 233-240.

Subedi, P., Pandit, N.P., Mahato, N.K., Karki, M. \& Uprety, A. 2019. Economic analysis of fish production using different feed types practiced in Dhanusha district, Nepal. Journal of Agriculture and Natural Resources, 2: 252-264. doi: 10.3126/janr.v2i1.26084

Tangendjaja, B. 2015. Quality control of feed ingredients for aquaculture. Feed and feeding practices in aquaculture. Elsevier, Amsterdam, pp. 141-169. doi: 10.1016/b978-0-08-100506-4.00006-4

Tibaldi, E., Uni, Z., Francesco, M., Luzzana, U., Harpaz, S., Tulli, F. \& Hakim, Y. 2006. Effects of the partial substitution of dietary fish meal by differently processed soybean meals on growth performance, nutrient digestibility and activity of intestinal brush border enzymes in the European seabass (Dicentrarchus labrax). Aquaculture, 261: 182-93. doi: 10.1016/j. aquaculture.2006.06.026

Received: 29 May 2020; Accepted: 27 August 2020
Tran, N., Chu, L., Chan, C.Y., Genschick, S., Phillips, M.J. \& Shula-Kefi, A. 2019. Fish supply and demand for food security in Sub-Saharan Africa: an analysis of the Zambian fish sector. Marine Policy, 99: 343-350. doi: 10.1016/j.marpol.2018.11.009

Wang, Y., Wang, L., Zhang, C.X. \& Song, K. 2017. Effects of substituting fishmeal with soybean meal on growth performance and intestinal morphology in orange-spotted grouper (Epinephelus coioides). Aquaculture Reports, 5: 52-57. doi: 10.1016/j.aqrep. 2016.12.005

Ye, H., Xu, M., Liu, Q., Sun, Z., Zou, C., Chen, L., et al. 2019. Effects of replacing fish meal with soybean meal on growth performance, feed utilization and physiological status of juvenile obscure puffer, Takifugu obscurus. Comparative Biochemistry and Physiology - Part C: Toxicology \& Pharmacology, 216: 75-81. doi: 10.1016/j.cbpc.2018.11.006

Zhang, C., Rahimnejad, S., Wang, Y.R., Lu, K., Song, K., Wang, L. \& Mai, K. 2018. Substituting fish meal with soybean meal in diets for Japanese seabass (Lateolabrax japonicus): effects on growth, digestive enzymes activity, gut histology, and expression of gut inflammatory and transporter genes. Aquaculture, 483: 173-182. doi: 10.1016/j.aquaculture.2017.10.029

Zhao, Z.X., Song, C.Y., Xie, J., Ge, X.P., Liu, B., Xia, S.L., et al. 2016. Effects of fish meal replacement by soybean peptide on growth performance, digestive enzyme activities, and immune responses of yellow catfish Pelteobagrus fulvidraco. Fisheries Science, 82: 665-73. doi: 10.1007/s12562-016-0996-6

Zhou, Z., Ringo, E., Olsen, R.E. \& Song, S.K. 2017. Dietary effects of soybean products on gut microbiota and immunity of aquatic animals: a review. Aquaculture Nutrition, 24: 644-665. doi: 10.1111/anu. 12532 